\title{
Comparison of the Transepicondylar Axis Measured Using Computed Tomography Before Primary Total Knee Arthroplasty and the Surgical Measurement
}

\author{
Zeki Taşdemir,, Güven Bulut, ${ }^{1}$ Özgür Baysal, ${ }^{2}$ Hüseyin Bilğehan Çevik,, Nurzat Elmalı
}

\author{
'Department of Orthopedics and \\ Traumatology, Kartal Dr. Lütfi Kırdar \\ Training and Research Hospital, \\ İstanbul, Turkey \\ ${ }^{2}$ Department of Orthopedics and \\ Traumatology, Kars Harakani State \\ Hospital, Kars, Turkey \\ ${ }^{3}$ Department of Orthopedics and \\ Traumatology, Bezmialem \\ Foundation University Faculty of \\ Medicine, İstanbul, Turkey \\ Submitted: 05.10.2017 \\ Accepted: 19.01.2018 \\ Correspondence: Zeki Taşdemir, \\ Kartal Dr. Lütfi Kırdar Eğitim ve \\ Araştırma Hastanesi, Ortopedi ve \\ Travmatoloji Kliniği, İstanbul, Turkey \\ E-mail:drtazeki@gmail.com
}

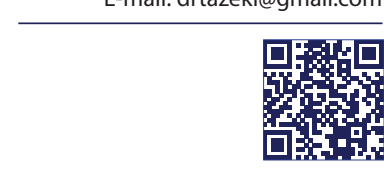

Keywords: Femoral component, posterior condylar axis; rotational alignment; transepicondylar axis; total knee arthroplasty.

\begin{abstract}
Objective: The purpose of this study was to evaluate the consistency of the angle between the posterior condylar line (PCL) and the transepicondylar axis (TEA) measured during surgery (sTEA) with that of the clinical transepicondylar axis (cTEA) measured using computerized tomography (CT) before primary total knee arthroplasty (TKA).
\end{abstract}

Methods: The records of patients who had undergone primary TKA between 2013 and 2105 and with a preoperative CT measurement of the knee were evaluated. During surgery, following the distal femoral incision, PCL and sTEA lines were drawn on the surface with a ruler and a pencil and recorded with a digital camera. The angle between the CTEA, or the line joining the most prominent points of the medial and lateral epicondyles, and the PCL was measured using a picture archiving communication system (PACS).

Results: The study group consisted of 9 knees of 9 patients (I male, 8 female; mean age: 67 years, range: $59-80$ years). The photographs indicating the angle between the sTEA line and the PCL revealed external rotation in 9 knees ( $100 \%)$, with a mean angle of $2.67 \pm 1.41^{\circ}$ (range: $\left.1-6^{\circ}\right)$. The preoperative axial CT images also demonstrated external rotation in 9 knees $(100 \%)$, with a mean angle of $4.67 \pm 1.41^{\circ}$ (range: $\left.2-7^{\circ}\right)$.

Conclusion: There was a difference between the sTEA, which is used to determine the rotation of femoral component during TKA, and the cTEA measured preoperatively using CT. It is safe to use I of these 2 techniques to check the result of the other. In the future, measurements made using CT will be used to design personalized anatomical prostheses.

\section{INTRODUCTION}

The rotational alignment of the femoral component is important for long-term survival of total knee arthroplasty (TKA) ${ }^{[1-5]}$ Inappropriate rotation can lead to patellar malalignment, anterior patellar pain, instability during femorotibial flexion, and premature attrition of the tibial insert. ${ }^{[6-10]}$ Important studies have demonstrated a higher rate of revision and unacceptable clinical outcomes in patient with rotational malalignment of tibial and femoral components. ${ }^{[6,7,11,12]}$ There are a number of valuable references used to judge femoral rotation: the Whiteside line, ${ }^{[13]}$ the transepicondylar axis, $(\text { TEA })^{[8,14-16]}$ the posterior condylar axis (PCA), ${ }^{[15]}$ ligament balancing, ${ }^{[14,17,18]}$ and the mechanical axis of the tibia. ${ }^{\left[{ }^{[9]}\right.}$ Currently, the femoral incision for total knee prosthesis is guided by the posterior femoral condyle. ${ }^{[20]}$ The objective of this study was to investigate the use of preoperatively obtained CT measurements to guide intraoperative planning of incisions made with reference to posterior femoral condyle. 


\section{MATERIAL AND METHODS}

This study is a retrospective cohort trial with Level III evidence. The records of patients who underwent primary TKA between 2013 and 2015 and with available preoperative knee CT images were evaluated. The patients had been informed previously that their CT scans and intraoperative photos would be stored in the archives of the clinic and used for publication, and the appropriate consent was obtained. The study was performed in compliance with the principles of the 2008 Helsinki Declaration. The operations were all performed by the same specialist in orthopedics and traumatology. During surgery, the distal femoral incision was made while the knee was at 900 flexion. Then, on the surface, the sTEA line was drawn using a pencil and a ruler between the most prominent points of the medial and lateral condyles, parallel to the

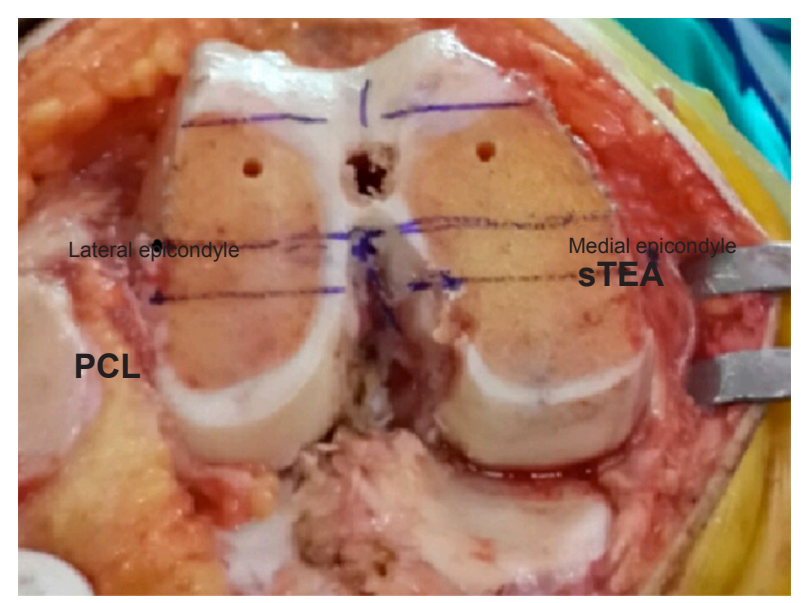

Figure 1. Angle between the intraoperative epicondylar and the posterior condylar axes.

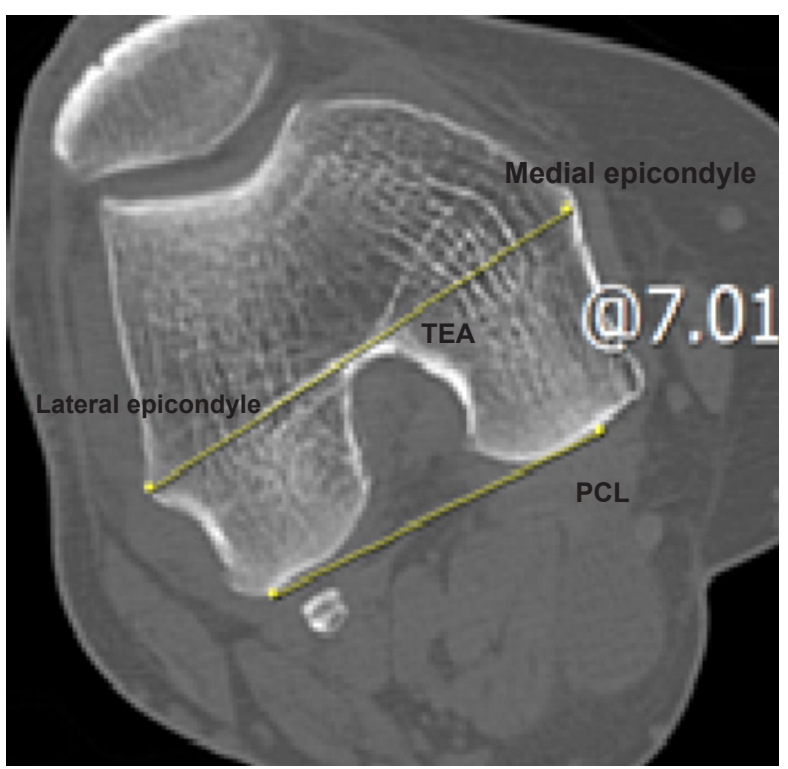

Figure 2. The angle between the epicondylar and posterior condylar axes as measured based on CT images.
PCL line drawn between the posterior condyles, and these lines were recorded with digital camera (Fig. I). The relevant angles in the images recorded were measured with a protractor.

The angle between the line drawn between the most prominent points of the lateral epicondyle and the most distant point of medial epicondyle, the CTEA, and the PCL line connecting the posterior condyles was measured using a picture archiving communication system (PACS) axial cross-section CT image of the femoral epicondyles (Fig. 2).

All measurements were made by 2 orthopedists and repeated 10 days later. The Tegner Lysholm Knee Scoring Scale (TLKSS) and the Visual Analogue Pain Scale (VAS) were administered to the patients preoperatively and postoperatively for clinical evaluation.

\section{RESULTS}

The study group comprised 9 knees of 9 patients (I male, 8 female; mean age: 67 years, range: $59-80$ years). The mean height of the patients was $160.4 \mathrm{~cm}$ (range: 150-175 $\mathrm{cm}$ ). Evaluation of the photographs indicating the angle between the sTEA line and the PCL revealed external rotation in 9 knees, with a mean angle of $2.67 \pm 1.41^{\circ}$ (range: $\left(-6^{\circ}\right)$. The preoperative axial CT images also demonstrated external rotation in 9 knees, with a mean angle of $4.67 \pm 1.41^{\circ}$ (range: $\left.2-7^{\circ}\right)$. There was a statistically significant difference between the 2 measurements $(p=0.00 \mathrm{I})$ (Table I, Fig. 3).

Intraobserver agreement between the 2 participating orthopedists on the 2 sets of measurements was excellent. (Table 2).

There was also excellent interobserver agreement on the cTEA and sTEA measurements (Table 3).

The mean preoperative TLKSS score was 45 points (range: 30-62 points), and the mean VAS score was $88 \mathrm{~mm}$ (range:

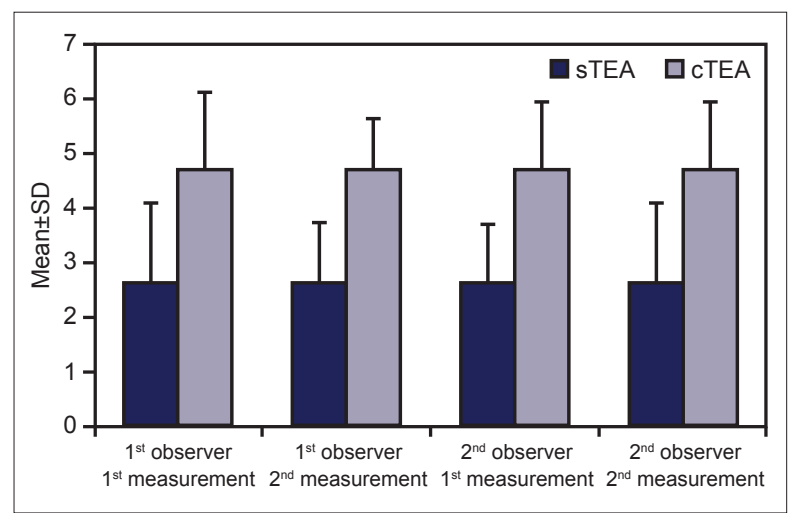

Figure 3. Preoperative cTEA measurements on CT images and sTEA measurements made on photos taken during surgery. cTEA: Clinical transepicondylar axis; sTEA: Surgical transepicondylar axis. 
Table I. General distribution of measurements

\begin{tabular}{|c|c|c|c|c|c|c|}
\hline & \multirow[t]{2}{*}{$\mathbf{n}$} & \multicolumn{2}{|c|}{ sTEA (photos) } & \multicolumn{2}{|c|}{ cTEA (CT) } & \multirow[t]{2}{*}{$\mathbf{p}$} \\
\hline & & Min-Max & Mean $\pm S D$ (median) & Min-Max & Mean $\pm S D$ (median) & \\
\hline First measurement of first observer & 9 & $1^{\circ}-6^{\circ}$ & $2.67 \pm I .4 \mid(2)$ & $3^{\circ}-7^{\circ}$ & $4.67 \pm I .4 \mid(2)$ & $0.006^{* *}$ \\
\hline Second measurement of first observer & 9 & $1^{\circ}-5^{\circ}$ & $2.56 \pm 1.13(2)$ & $3^{\circ}-6^{\circ}$ & $4.56 \pm 1.01(2)$ & $0.007^{* *}$ \\
\hline First measurement of second observer & 9 & $2^{\circ}-5^{\circ}$ & $2.67 \pm 1.00(2)$ & $3^{\circ}-7^{\circ}$ & $4.67 \pm 1.22(2)$ & $0.007^{* *}$ \\
\hline Second measurement of second observer & 9 & $1^{\circ}-6^{\circ}$ & $2.67 \pm I .4 \mid(2)$ & $3^{\circ}-7^{\circ}$ & $4.67 \pm 1.22(2)$ & $0.007^{* *}$ \\
\hline
\end{tabular}

Wilcoxon signed rank test. " ${ }^{*}<0.01$. sTEA: Surgical transepicondylar axis; $c$ TEA: Clinical transepicondylar axis; CT: computerized tomography; Min: Minimum; Max: Maximum; SD: Standard deviation.

Table 2. Intraobserver agreement between the first and the second measurements

\begin{tabular}{|c|c|c|c|c|c|c|c|c|}
\hline \multirow[b]{2}{*}{ Measure single } & \multirow[b]{2}{*}{ ICC } & \multicolumn{2}{|c|}{$95 \% \mathrm{Cl}$} & \multicolumn{4}{|c|}{ F Test with true value } & \multirow[t]{2}{*}{ Power } \\
\hline & & Lower bound & Upper bound & Value & dfI & df2 & $\mathbf{p}$ & \\
\hline \multicolumn{9}{|c|}{ cTEA Ist measurement $-2^{\text {nd }}$ measurement } \\
\hline First observer & $0.890^{\mathrm{a}}$ & 0.589 & 0.974 & 17.154 & 8 & 8 & $0.000^{* *}$ & 0.870 \\
\hline Second observer & $0.833^{\mathrm{a}}$ & 0.425 & 0.960 & 11.000 & 8 & 8 & $0.001^{* *}$ & 0.696 \\
\hline \multicolumn{9}{|c|}{ sTEA I st measurement $-2^{\text {nd }}$ measurement } \\
\hline First observer & $0.88 I^{\mathrm{a}}$ & 0.561 & 0.972 & 15.769 & 8 & 8 & $0.000^{* *}$ & 0.845 \\
\hline Second observer & $1.000^{\mathrm{a}}$ & 1.000 & 1.000 & - & 8 & - & - & 1.000 \\
\hline
\end{tabular}

${ }^{a}$ Excellent agreement. ${ }^{*} \mathrm{p}<0$. sTEA: Surgical transepicondylar axis; cTEA: Clinical transepicondylar axis; ICC: Intraclass correlation coefficient.

Table 3. Level of interobserver consistency

\begin{tabular}{|c|c|c|c|c|c|c|c|c|}
\hline \multirow[b]{2}{*}{ Measure single } & \multirow[b]{2}{*}{ ICC } & \multicolumn{2}{|c|}{$95 \% \mathrm{Cl}$} & \multicolumn{4}{|c|}{ F Test with true value } & \multirow[t]{2}{*}{ Power } \\
\hline & & Lower bound & Upper bound & Value & dfl & df2 & $\mathbf{p}$ & \\
\hline \multicolumn{9}{|c|}{ cTEA Ist observer-2 $2^{\text {nd }}$ observer } \\
\hline$I^{\text {st }}$ measurement & $0.917 \mathrm{a}$ & 0.677 & 0.981 & 23.000 & 8 & 8 & $0.000^{* *}$ & 0.935 \\
\hline $2^{\text {nd }}$ measurement & $0.890 \mathrm{a}$ & 0.589 & 0.974 & 17.154 & 8 & 8 & $0.000^{* *}$ & 0.870 \\
\hline \multicolumn{9}{|c|}{ sTEA I ${ }^{\text {st }}$ observer- $2^{\text {nd }}$ observer } \\
\hline$I^{\text {st }}$ measurement & $0.929 \mathrm{a}$ & 0.718 & 0.983 & 27.000 & 8 & 8 & $0.000^{* *}$ & 0.958 \\
\hline $2^{\text {nd }}$ measurement & $0.956 a$ & 0.819 & 0.990 & 44.500 & 8 & 8 & $0.000^{* *}$ & 0.990 \\
\hline
\end{tabular}

${ }^{2}$ Excellent agreement. ${ }^{*} \mathrm{p}<0.01$. sTEA: Surgical transepicondylar axis; cTEA: Clinical transepicondylar axis; ICC: Intraclass correlation coefficient.

70-98 mm). The mean postoperative TLKSS score was 78 points (range: $68-90$ points), and the mean VAS score was $40 \mathrm{~mm}$ (range: $32-58 \mathrm{~mm}$ ).

\section{DISCUSSION}

The results of this study revealed a significant difference between the sTEA measurement used in the intraoperative determination of the rotation of the femoral component and the cTEA measured preoperatively based on CT images. The relationship between the posterior condylar axis and the TEA can be determined radiologically with $\mathrm{CT}$. As a result, instead of routinely using $\mathrm{PCL}$ $+3^{\circ}$ as a routine guide, rotation of the femoral component can be anatomically restored using adjustable guidelines based on PCL values that can be preoperatively measured (PCA+measurable external rotation), reducing the possibility of intraoperative measurement errors. When 3-dimensional anatomy of lateral epicondyle is considered, the highest points of the medial epicondyle form a crescent 
facing upwards. Palpation can provide clarification; however, while the peak point of lateral epicondyle can be felt easily, palpation of the medial epicondyle is more difficult.

During movements of flexion and extension of the knee, the femoral condyle rotates around a stable axis. This axis corresponds to the line drawn between adhesion points of the collateral ligaments. The TEA is the closest line to this axis. Therefore, the axial plane of the femoral implant is parallel to the TEA. ${ }^{[21-23]}$

Some important references used to determine femoral rotation are the Whiteside ${ }^{[13]}$ line, the TEA, ${ }^{[8,14-16]}$ the PCA, ${ }^{[15]}$ ligament balancing, ${ }^{[14,17,18]}$ and the tibial mechanical axis. ${ }^{[19]}$ None of these methods is superior to the other. Computer-assisted navigation systems used to determine rotation of the femoral component are not more suitable than traditional techniques. ${ }^{[2]}$ Many authors have emphasized the need for further improvement in navigation technologies used to precisely measure femoral rotation. ${ }^{[25-28]}$

Stulberg ${ }^{[26]}$ found a difference of $4.69^{\circ}$ internal rotation between pre- and postoperative CT measurements, the PCA, and the TEA, and did not consider intraoperative techniques used for the determination of the PCL and the TEA to be sufficiently accurate.

Boya et al. ${ }^{[29]}$ evaluated the consistency between an intraoperatively drawn TEA and a PCA $+3^{\circ}$ external rotation line, and they found that these measurements were consistent in 22 of 36 knees. They detected internal rotation in 10 cases and external rotation in 4 . A 30 external rotation with reference to PCA may not be consistent with the anatomical TEA of the patient. In our study, all of the sTEA lines demonstrated external rotation. The mean angle of the sTEA line drawn during surgery $2.67 \pm 1.41^{\circ}$ (range: $1-6^{\circ}$ ) and the mean angle of the preoperative cTEA was $4.67 \pm 1.41^{\circ}$ (range: $2-7^{\circ}$ ).

Behera et al. ${ }^{[30]}$ found comparable results when they evaluated the PCA (the angle between the PCL and the TEA) based on CT images using 2 different methods (trigonometric measurement and a protractor). They reported that preoperative evaluation based on CT is essential. The difference between the intraoperatively calculated PCA and that based on preoperative CT found in our study supports the need for a preoperative CT assessment.

The lack of a control group and the small number of patients are limitations of our study. Clinical comparison of cases with a femoral incision planned based on preoperative CT measurements and those performed based on an intraoperatively determined femoral axis will yield valuable results.

\section{Conclusion}

In this study, the external rotation angle based on a preoperatively drawn TEA line using $\mathrm{CT}$ was greater than that measured intraoperatively. Though determination of the femoral rotation axis with CT is not absolutely necessary, we can say that preoperative measurement (radiology, CT) may be useful for satisfactory clinical improvement. It is safe to use one of these techniques to check the result of the other. In the future, measurements made with $\mathrm{CT}$ will be used to design individualized anatomical prostheses.

Ethics Committee Approval

Ministry of Health Kartal Dr. Lütfi Kırdar Training and Research Hospital Ethical Committee. Decision no: $2017 / 514 / 111 / 5$. Informed consent to participate in the study was obtained from all participants.

\section{Informed Consent}

Retrospective study.

Peer-review

Internally peer-reviewed.

Authorship Contributions

Concept: Z.T., N.E.; Design: G.B.; Data collection \&/or processing: Ö.B., H.B.Ç.; Analysis and/or interpretation: Z.T., H.B.Ç.; Literature search: G.B., Z.T., N.E.; Writing: Z.T., G.B.; Critical review: N.E.

Conflict of Interest

None declared.

\section{REFERENCES}

1. Akagi M, Matsusue Y, Mata T, Asada Y, Horiguchi M, Iida H, et al. Effect of rotational alignment on patellar tracking in total knee arthroplasty. Clin Orthop Relat Res 1999:155-63. [CrossRef]

2. Anouchi YS, Whiteside LA, Kaiser AD, Milliano MT. The effects of axial rotational alignment of the femoral component on knee stability and patellar tracking in total knee arthroplasty demonstrated on autopsy specimens. Clin Orthop Relat Res 1993:170-7. [CrossRef]

3. Berger RA, Crossett LS, Jacobs JJ, Rubash HE. Malrotation causing patellofemoral complications after total knee arthroplasty. Clin Orthop Relat Res 1998:144-53. [CrossRef]

4. Moon YW, Seo JG, Lim SJ, Yang JH. Variability in femoral component rotation reference axes measured during navigation-assisted total knee arthroplasty using gap technique. J Arthroplasty 2010;25:238-43.

5. Moreland JR, Bassett LW, Hanker GJ. Radiographic analysis of the axial alignment of the lower extremity. J Bone Joint Surg Am 1987;69:745-9. [CrossRef]

6. Hofmann S, Romero J, Roth-Schiffl E, Albrecht T. Rotational malalignment of the components may cause chronic pain or early failure in total knee arthroplasty. Orthopade 2003;32:469-76. [CrossRef]

7. Wasielewski RC, Galante JO, Leighty RM, Natarajan RN, Rosenberg AG. Wear patterns on retrieved polyethylene tibial inserts and their relationship to technical considerations during total knee arthroplasty. Clin Orthop Relat Res 1994:31-43. [CrossRef]

8. Berger RA, Rubash HE, Seel MJ, Thompson WH, Crossett LS. Determining the rotational alignment of the femoral component in total knee arthroplasty using the epicondylar axis. Clin Orthop Relat Res 1993:40-7. [CrossRef] 
9. Figgie HE 3rd, Goldberg VM, Figgie MP, Inglis AE, Kelly M, Sobel M. The effect of alignment of the implant on fractures of the patella after condylar total knee arthroplasty. J Bone Joint Surg Am 1989;71:1031-9. [CrossRef]

10. Oswald MH, Jakob RP, Schneider E, Hoogewoud HM. Radiological analysis of normal axial alignment of femur and tibia in view of total knee arthroplasty. J Arthroplasty 1993;8:419-26. [CrossRef]

11. Romero J, Stähelin T, Binkert C, Pfirrmann C, Hodler J, Kessler O. The clinical consequences of flexion gap asymmetry in total knee arthroplasty. J Arthroplasty 2007;22:235-40. [CrossRef]

12. Incavo SJ, Wild JJ, Coughlin KM, Beynnon BD. Early revision for component malrotation in total knee arthroplasty. Clin Orthop Relat Res 2007;458:131-6. [CrossRef]

13. Whiteside LA, Arima J. The anteroposterior axis for femoral rotational alignment in valgus total knee arthroplasty. Clin Orthop Relat Res 1995:168-72. [CrossRef]

14. Insall JN, Binazzi R, Soudry M, Mestriner LA. Total knee arthroplasty. Clin Orthop Relat Res 1985:13-22. [CrossRef]

15. Laskin RS. Flexion space configuration in total knee arthroplasty. J Arthroplasty 1995;10:657-60. [CrossRef]

16. Mantas JP, Bloebaum RD, Skedros JG, Hofmann AA. Implications of reference axes used for rotational alignment of the femoral component in primary and revision knee arthroplasty. J Arthroplasty 1992;7:531-5. [CrossRef]

17. Olcott CW, Scott RD. Determining proper femoral component rotational alignment during total knee arthroplasty. Am J Knee Surg 2000;13:166-8.

18. Stiehl JB, Cherveny PM. Femoral rotational alignment using the tibial shaft axis in total knee arthroplasty. Clin Orthop Relat Res 1996:47-55. [CrossRef]

19. Stiehl JB, Abbott B: Femoral component rotational alignment using the extramedullary tibia1 shaft axis: A technical note. J Orthop Rheumatol 1995;8:93-6.
20. Berger RA, Rubash HE. Rotational instability and malrotation after total knee arthroplasty. Orthop Clin North Am 2001;32:639-47.

21. Churchill DL, Incavo SJ, Johnson CC, Beynnon BD. The transepicondylar axis approximates the optimal flexion axis of the knee. Clin Orthop Relat Res 1998:111-8. [CrossRef]

22. Yoshioka $Y$, Siu D, Cooke TD. The anatomy and functional axes of the femur. J Bone Joint Surg Am 1987;69:873-80. [CrossRef]

23. Akagi M, Yamashita E, Nakagawa T, Asano T, Nakamura T. Relationship between frontal knee alignment and reference axes in the distal femur. Clin Orthop Relat Res 2001:147-56. [CrossRef]

24. Siston RA, Patel JJ, Goodman SB, Delp SL, Giori NJ. The variability of femoral rotational alignment in total knee arthroplasty.J Bone Joint Surg Am 2005;87:2276-80. [CrossRef]

25. Saragaglia D, Picard F, Chaussard C, Montbarbon E, Leitner F, Cinquin P. Computer-assisted knee arthroplasty: comparison with a conventional procedure. Results of 50 cases in a prospective randomized study. Rev Chir Orthop Reparatrice Appar Mot 2001;87:18-28.

26. Stulberg SD. How accurate is current TKR instrumentation? Clin Orthop Relat Res 2003:177-84. [CrossRef]

27. Chauhan SK, Scott RG, Breidahl W, Beaver RJ. Computer-assisted knee arthroplasty versus a conventional jig-based technique. A randomised, prospective trial. J Bone Joint Surg Br 2004;86:372-7.

28. Jenny JY, Boeri C. Computer-assisted implantation of a total knee arthroplasty: a case-controlled study in comparison with classical instrumentation. Rev Chir Orthop Reparatrice Appar Mot 2001;87:645-52.

29. Boya H, Özcan Ö, Maralcan G. An investigation of consistency between posterior condylar axis +3 degree external rotation line and clinical transepicondylar axis line techniques in primary total knee arthroplasty. Eklem Hastalık Cerrahisi 2014;25:70-4. [CrossRef]

30. Behera P, Chouhan DK, Prakash M, Dhillon M. Proposed Methods for Real-Time Measurement of Posterior Condylar Angle during TKA. Knee Surg Relat Res 2014;26:230-5. [CrossRef]

\section{Primer Total Diz Protezi Öncesinde Bilgisayarlı Tomografi Yardımıyla Ölçülen Transepikondiler Aks İle Cerrahi Transepikondiler Aksın Karşılaştırılması}

Amaç: Bu çalışmanın amacı primer total diz protezi (TDP) uygulamalarında posterior kondiler çizgi (PCL) ve cerrahi sırasındaki anatomik transepikondiler aks (saTEA) çizgisi arasındaki açı ile ameliyat öncesi bilgisiyarlı tomografi (BT) çekilmiş hastalarda klinik anatomik transepikondiler aks (caTEA) arasındaki açı uyumluluğunun araştırılmasıdır.

Gereç ve Yöntem: 20I3-20I5 yılları arasında primer TDP yapılan ve preoperatif diz BT'si mevcut olan hastalar değerlendirildi. Ameliyat sırasında distal femur kesisini takiben kesi yüzeyine kalem ve cetvel ile PCL ve saTEA çizgileri çizildi ve dijital kamera ile kaydedildi. "Picture Archiving Communication Systems" (PACS) üzerinde BT aksiyel femur kesitlerinde, lateral epikondil çıkıntısının en belirgin olduğu bölgeden medial epikondilin en uç noktasına çekilen çizgi (caTEA) ile posterior kondillerden geçen çizgi (PCL) arasındaki açı belirlendi.

Bulgular: Dokuz hastanın ( I erkek, 8 kadın; ortalama yaş 67 [59-80 yaş]) dokuz dizi çalışma grubunu oluşturdu. Fotoğraflar ve BT'de aksiyel kesit üzerinde yapılan ölçümler değerlendirildiğinde, saTEA çizgisi PCL çizgisiyle kıyaslandığında dokuz dizde (\%।00) dış rotasyon, ortalama açı $2.67 \pm 1.41^{\circ}\left(1^{\circ}-6^{\circ}\right)$ olduğu; ameliyat öncesi BT ile yapılan ölçümlerde de dokuz dizde dış rotasyon, ortalama açı $4.67 \pm 1.41^{\circ}\left(2^{\circ}-7^{\circ}\right)$ olduğu tespit edildi.

Sonuç: Total diz protezi ameliyatı sırasında femoral komponentin rotasyonunun tespitinde kullanılan saTEA ile ameliyat öncesi BT'de ölçülen caTEA arasında fark bulunmuştur. Bu iki teknikten birinin diğerinin sonucunu kontrol etmek için kullanılması güvenlidir. Gelecekte yapılabilecek olan kişiye özgü anatomik protezlerde BT ile yapılan ölçümlerin yeri olacaktır.

Anahtar Sözcükler: Femoral komponent; posterior kondiler aks; rotasyonel dizilim; transepikondiler aks; total diz protezi. 